postulated a nucleus of gneiss and granite in the central part of northern Peary Land and believed that the blocks of granite he found on the north coast of Peary Land were derived from it. This high-grade nucleus, which was disputed by EllitsgaardRasmussen (1955), is now known through field work in the area to be definitely non-existent and the highest grade rocks exposed are garnet-biotite psammites and schists (see Dawes \& Soper, this report). Either the gneiss and granite pebbles and boulders come from the same crystalline region as the granitic and gneissic pebbles recorded in the glacial till of southern Peary Land, in which case they may be a good indication of the northerly extent of part of the ice cap along the coast, or they have been derived from the north. In the latter case they may be either locally derived and an indication of the type of rocks existing on the shelf off the coast of North Greenland or they have been carried long distances across the Arctic Ocean and represent the high-grade rocks of another land mass.

\title{
References
}

Davies. W. E. 1961 : Glacial geology of northern Greenland. Polarforschung 5. Jahrg. 31. 94-103.

Ellitsgaard-Rasmussen, K. 1955: Features of the geology of the folding range of Peury Land North Greenland. Meddr Gronkand 127. 7.

Koch. L. 1923: Resultaterne af Jubilæumsekspeditionen Nord om Grønland i 1921. Nafurens Verden 7. 49-76.

Koch. L. 1928: The physiography of North Greenland. In Vahl. M. et al. (edit.): Greenland 1. 491-518. Copenhagen: C. A. Reitzel.

Troelsen, J. C. 1952: Notes on the Pleistocene geology of Peary Land, North Greenland. Meddr dansk geol. Foren. 12, 209-220.

\section{LATE PRECAMBRIAN MICROFOSSILS FROM PEARY LAND}

\section{K. Raunsgaard Pedersen}

Examinations of a black chert from the late Precambrium (Eocambrium) of the southern part of Peary Land have revealed several types of microfossils, some of which show affinities to a flora of about the same age from Australia.

During the summer of 1968 the Precambrian and Eocambrian sediments of Jørgen Brønlund Fjord area in southern Peary Land were studied by Jepsen (1969), who brought home the chert sample examined.

The black chert comes from a dolomite series with cherty layers and lenses; it was collected about $100 \mathrm{~m}$ above the upper of the two unconformities (see fig. 2 in Jepsen, 1969). In the upper part of this dolomite series Collenia structures are common (Jepsen, pers. comm.).

The age of the dolomite series is stated as Eocambrium? as it lies between the Lower 
Cambrian Brønlunds Fjord dolomite and a tillite at the base of which the boundary of the Eocambrian is placed. A dating of the discordant sills in the Precambrian below the tillite has recently given an age of about 1000 m. y. (see Henriksen \& Jepsen, this report).

The chert sample is black in colour; it shows a layer a few $\mathrm{cm}$ thick with abundant ooliths, the diameter of which is up to about $3 \mathrm{~mm}$. A section perpendicular to the bedding plane shows that most of the ooliths are of a flat elliptical shape and many are lying oriented in about the same way following the bedding plane. Many of the ooliths are in contact with each other.

The microfossils are found between and within the ooliths with a clear concentration in the outer part of the ooliths.

A thread-formed microfossil is very abundant. It shows close affinity to the genus Eomycetopsis described from the late Precambrian of Australia (Schopf, 1968). It consists of long unbranched tubes with distinct, rather thick, granulate walls. The diameter varies around 4 micron and the length is up to 400 micron. The tubes occur in dense clusters or as long straight single tubes. Only a few indistinct septations are observed in the tubes. Another type of microfossil from the chert also closely resembles the Australian flora described by Schopf. It has a globular form with a diameter of 120 micron and is related to colonies of the genus Myxococcoides.

Besides these two forms others have been observed.

Organo-chemical investigations of the material have not been carried out because too little material is available but it is hoped that new collections can be made in the coming years.

\section{References}

Jepsen, H. 1969: Preliminary report on the stratigraphy of the Precambrian and Eocambrian sediments in the Jørgen Brønlunds Fjord - Midsommersø area, southern Peary Land. Rapp. Grønlands geol. Unders. 19, 11-14.

Schopf, W. 1968: Microflora of the Bitter Springs formation, late Precambrian, Central Australia. J. Paleont. 42, 3, 651-688.

\section{FIELD WORK IN THE AGTO - NORDRE STRØMFJORD REGION}

\section{E. Bondesen}

Mapping in the Agto region was continued in 1969; during this, the fourth, season seven teams participated. The following review of the season's work summarises only the new information. Outlines of the general geology of the area are to be found in previous annual reports and $\mathrm{K}$. Sørensen (in press). 